\title{
The Role of Textbooks in Primary Education
}

\section{Jana Stará, Martin Chvál, Karel Starý}

\begin{abstract}
The article presents the results of a research with the objective of finding out what kind of influence textbooks have on teachers' decisions about the content and methods of their teaching, especially in comparison with other materials and factors. The research was particularly aimed at teachers of primary schools and textbooks and other teaching materials for social studies and sciences. The results show that even though the teachers believe that textbooks have a major influence on their teaching, they disagree with the idea that textbooks should determine the content and methods of teaching. The article will present you with some thoughts on how to overcome this contradiction.
\end{abstract}

Keywords: primary education, use of textbooks, textbooks.

\section{Role učebnic v primárním vzdělávání}

\begin{abstract}
Abstrakt
Článek představuje výsledky kvantitativně orientovaného výzkumu, jehož cílem bylo zjistit, jaký vliv mají učebnice na rozhodování učitelů o obsahu a metodách výuky, obzvláště v porovnání s ostatními materiály a faktory. Výzkum byl zaměřen na učitele 1. stupně ZŠ a učebnice prvouky, prírodovědy a vlastivědy (vzdělávací oblast Člověk a jeho svět). Výsledky ukazují, že navzdory tomu, že učitelé věří, že učebnice mají velký
\end{abstract}


vliv na jejich výuku, nesouhlasí s myšlenkou, že by učebnice měly určovat obsah a metody výuky. Článek se mj. zamýšlí nad tím, jak tento rozpor překonat.

Klíčová slova: primární vzdělávání, použití učebnic, učebnice.

\section{Introduction}

The international comparisons of data collected on classroom teaching and learning resources from TIMSS indicates the following: Despite the politicians' claims that digital media are the teaching tool of the future, printed textbooks still play a major role among other classroom curricular resources (Horsley and Sikorova, 2014). According to the TIMSS 2011 study, more than $70 \%$ of students were taught by using textbooks as the basis of instruction. Other teaching and learning tools, such as worksheets or computer software, were used just as an addition to the lessons. According to this study, from 2003/2007 to 2011, the percentage of teachers using textbooks as the basis of instruction increased. This phenomenon appeared significantly during lessons of fourth grade science and fourth and eighth grade mathematics. Logically, the percentage of teachers who used textbooks just as a supplement for their instruction decreased for the same grades and subjects as mentioned above (Horsley and Sikorova, 2014).

Even though previous studies indicate these results about the usage of textbooks, this study is another attempt to address the issue of the influence of textbooks on other elements in education, for instance teachers' personal beliefs, shared school beliefs, and factors set by the government and the school management.

If the students are provided with multiple learning resources, it is essential to ponder how these different sources interact with each other. The textbooks need to be linked and integrated with other resources (Horsley, Knight and Huntly, 2010). The current society demands supporting individual students'learning and taking into account the local context of teaching and learning (Seoane and Rodríguez, 2014). Furthermore, the demand underpins the claim to look at textbooks as resources that mediate and support mutual creation of learning by teachers, pupils, and textbooks. The concept of participation on the text coined by Remillard (2005) is being introduced to the students of Faculties of Education. They ought to adapt and interpret texts and in the process of working with the texts students should undergo changes themselves. At the same time, the content of a textbook is a product of sociocultural development; as such, it is retrospectively formed by both teachers' and pupils' actions (Brown, 1992; Dvořák et al., 2008, p. 83; DBRC, 2003; Wang and Hannafin, 2005). Pinar et al. (2004, p. 699-704) mention the approach called curriculum enactment in which the implementation requires a change in teachers' thinking. 
Teachers individually develop themselves and change their way of thinking as well as their behaviour while working with a curriculum and textbooks. This process could thus be referred to as curriculum/textbook development rather than just its implementation.

As argued above there is a need to look at the textbook usage as the result of many factors that are in mutual relationships. Emphasizing on this phenomenon could create a new system of pedagogical education by using the available curricula materials more effectively. The understanding could support individual needs of pupils and the requirements of class environment.

In the research that is being presented in this article, the following research question was asked: What is the influence of textbooks on teachers' decisions about the content and the methods of their teaching, especially in comparison with other materials and factors?

\section{Methods}

The survey of this study was conducted via an online questionnaire. About 310 of the 592 teachers who completed the questionnaire did not comment on any question and 181 filled in all required data. The remaining 99 respondents answered only to some parts of the questionnaire; the main reason was probably the time limit since answering the questionnaire took only twenty minutes on average.

The participants were primary education teachers (ISCED 1), mostly women (97.8\%) and fully qualified teacher (71.8\%). The online questionnaire was sent to 390 selected alumni (who graduated in 2013-2015) from Faculties of Education. We had selected alumni from three different Czech universities with the purpose of distributing the questionnaire to their colleagues. The questionnaire was sent to all the alumni whose e-mail addresses the researcher and the co-workers from other universities had thanks to previous courses.

The data was collected from February 2015 to June 2016. The online questionnaire consisted of 160 items divided into seven sets of questions. The items focused mainly on the influence of primary science and social studies textbooks. The questionnaire also dealt with problems such as modifying textbooks, the qualities of ideal textbooks, other factors influencing instruction and the use of different sources in instruction. Most items contained a five-point Likert scale and the participants were also asked to order different quotes according to their importance.

In this paper the part of the research which refers to the influence of textbooks on the content and the methods of teaching is given most prominence to. 


\section{Results}

\section{Factors Influencing the Content and the Methods of Teaching}

The following charts represent the results of the research concerning the influence of textbooks and other educational factors, such as curricula baselines, monthly teaching plans, teacher's personal beliefs, teacher's guidelines, and shared school beliefs on the choosing of the content of instruction (figure 1) and the teaching methods (figure 2).

Figure 1

Influence on WHAT I teach (content), N = 286

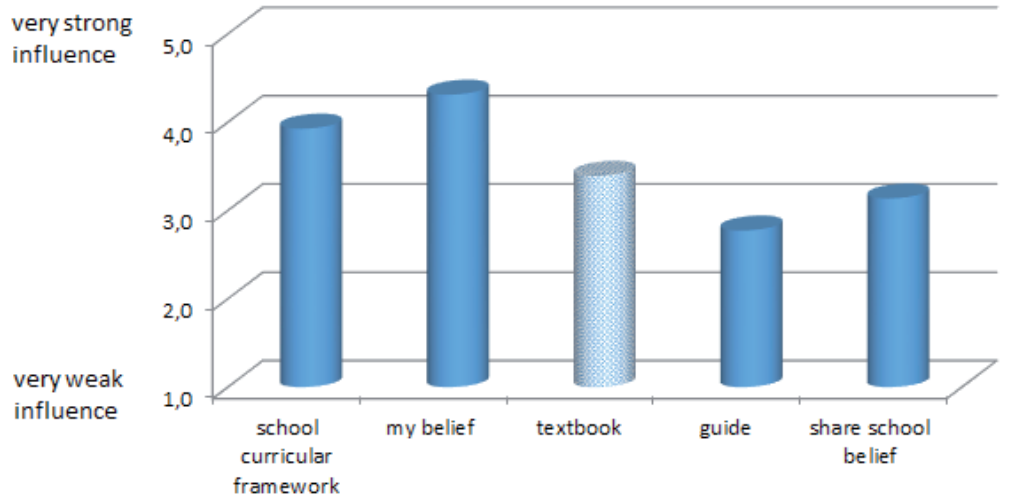

Figure 2

Influence on HOW I teach (methods), $\mathrm{N}=260$

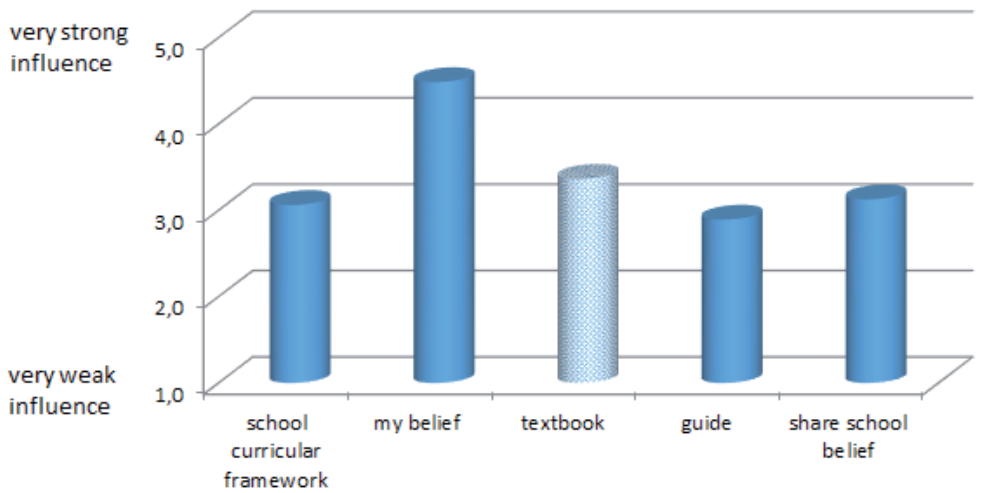




\subsection{Use of Educational Resources}

Among individual educational resources, textbooks play the main role in everyday education as they are used every second or third lesson on average. The use of encyclopedias, various educational software and teachers'/colleagues' handouts is relatively low. On the other hand, teachers work with internet sources and their own handouts quite often (figure 3). As for the use of different educational resources, we have neglected a significant difference between beginning and experienced teachers. Experienced teachers tend to use encyclopedias and educational software more than beginning teachers. This issue has not been fully examined yet and we are willing to gather data from more participants in the future.

\section{Figure 3}

Use of educational resources
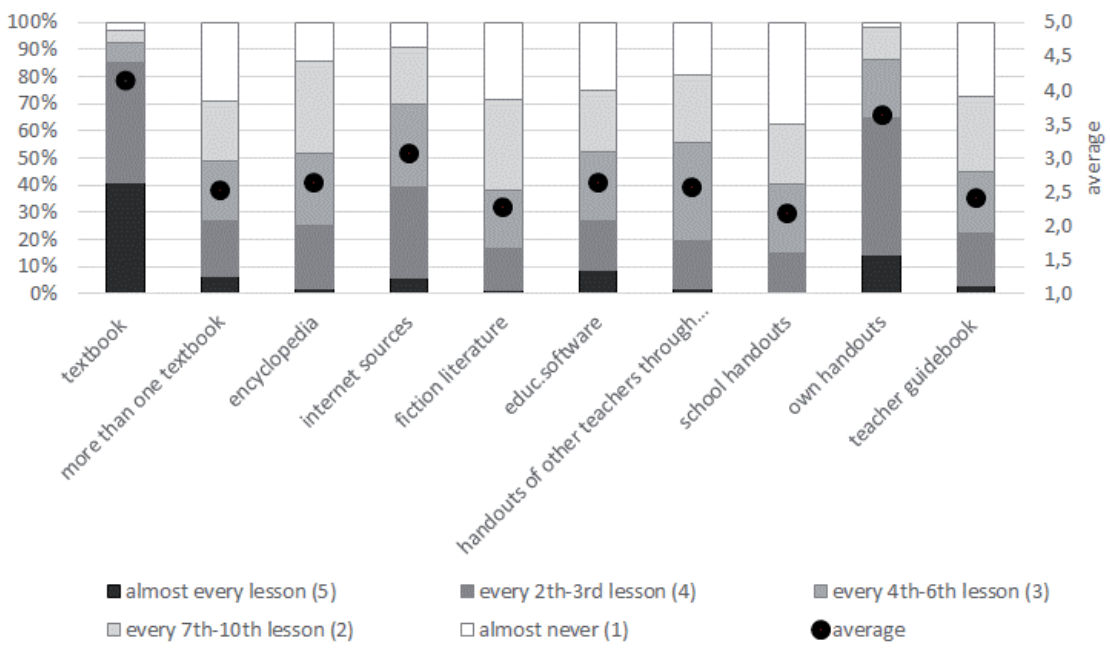

\subsection{Teachers' Opinions about the Function of Textbooks During Instruction}

The answers about defining the role of textbooks have not completely reflected their actual role. Yet these answers have brought plenty of information about the teachers' beliefs in this area. The majority of teachers are convinced that textbooks should not determine the way they teach. Concerning the questions about influencing the teaching content, teachers answered that they do not believe textbooks must or should 
guarantee the completeness of curricula. The same goes for the role of textbooks as tools to ensure proper content selection; approximately one half of the teachers do not claim that textbooks should play this role. The majority of respondents believe that teachers should develop their own worksheets for supporting individual needs of their pupils. In our extended research we will ask the teachers for which pupils they adapt and create their materials. Finally, we will inquire into what the differences in adapting the materials are between beginning and experienced teachers.

Figure 4

Teachers' opinions on the function of textbooks in instruction

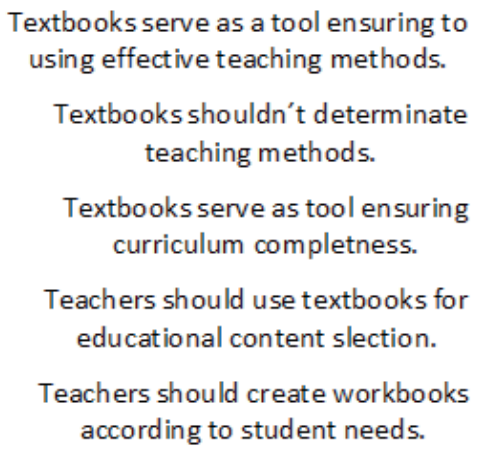

Textbooks serve as a tool ensuring to using effective teaching methods.

Textbooks shouldn't determinate teaching methods.

Textbooks serve as tool ensuring curriculum completness.

Teachers should use textbooks for educational content slection.

Teachers should create workbooks according to student needs.

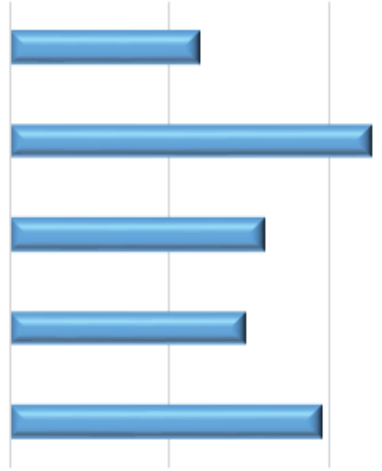

$\begin{array}{lccc}\begin{array}{c}1,0 \\ \text { ompletely } \\ \text { disagree }\end{array} & 2,0 & 3,0 & \begin{array}{c}4,0 \\ \text { completely } \\ \text { agree }\end{array}\end{array}$

\section{Discussion}

Considering the fact that the respondents were addressed by the university staff or teachers' colleagues, it is not possible to generalize the results. However, it can be claimed that the interpretation of the results could lead to a better understanding of the discussed issue. It might also encourage us to design a further research in this area, which may include answering to recently discovered questions.

Although the qualitative surveys (Stará and Krčmářová, 2014; Stará, Dvořáková and Dvořák, 2010) and their generalizations showed that curricula reforms (based on implementing school curricula) resulted in unmanageable formalism (Janík, 2013; compare also with Dvorák, 2015 and Rendl, and Štech, 2012), the current research seems to validate the view that teachers consider school curricula to be frameworks for planning and 
realizing their training. Rather influential are also monthly teaching plans developed by teachers in individual schools.

In any case, our findings indicate that teachers think that it is mainly their belief to determine their way of teaching. This claim is in correspondence with our previous conclusions from the qualitative studies mentioned above. According to the study of Stará and Krčmářová (2014) teachers see it as an indisputable fact that the selection of the subject matter is at their discretion, according to their own preferences and experiences, which is something they truly welcome.

The results of our study, as of many other former ones (Sikorová 2011, Peacock and Gates 2000, Lambert 1996, Grossman and Thompson 2008), appear to validate that printed textbooks are still essential. A closer look at the data indicates that teachers are willing to work with other resources, even though they actually do not do that very often. Taking into consideration that the research focuses on teachers of primary social studies and science, the average use of encyclopedia (see fig. 3) is surprisingly low. Similarly, the use of educational software is below average (fig. 3). It is despite the fact that many experts call for increased usage of educational software in order to develop pupils' digital competency (Rambousek, et al., 2015). This fact can be caused by the low competency or willingness of teachers to use educational software because of their low skill in combining different sources for fulfilling the goals of the instruction etc. It might also be caused by the shortage of ICT software at schools (EURYDICE 2011), which could potentially be an even greater problem than the lack of computer hardware in schools.

As Horsley and Sikorova (2014) state, the role of textbooks is changing. Traditionally, teaching was based on information transmission and textbooks served mainly as tools enabling it. In the constructivist way of teaching, textbooks serve mainly as guidelines for learning and learning management. Textbooks are transforming into a source of activities and inquiries and also have co-ordination and integrative functions (Stará and Krčmářová, 2014b). Mikk (2000, p. 18) claims that textbooks should be used with other educational aids like videos/animations, worksheets or computer programs. It is not possible to discern whether the answers of teachers (fig. 4) in our survey reflect their beliefs on the coordinating role of textbooks or not. A qualitative research in this area should bring more answers.

\section{Conclusion}

The majority of teachers are convinced that textbooks should not determine the way they teach. They do not believe textbooks should guarantee the completeness of curricula and most of them believe that teachers should develop their own worksheets for supporting individual needs of their pupils. This result is in contradiction with the 
other result of our study, namely that textbooks play the dominant role in instruction and that other teaching resources are used surprisingly infrequently.

Summing up the results, it can be concluded that a new challenge for the designers of textbooks is to create materials that would enable teachers to put the finishing touches to the textbooks' framework and to feel free to decide to use additional materials or resources according to their own beliefs about the proper way of teaching. The challenge for pedagogical education could be to help both future and current teachers to reflect their beliefs and to develop their skills. Furthermore, teachers should be able to use different resources to fulfill systematic goals of instruction.

According to Grossman and Thompson (2008), pedagogical lectors often advise their students to minimize the usage of textbooks for its poor qualities. Instead, students are encouraged to create their own worksheets. On the other hand, some researches (Ball and Sharon, 1988) show that average students would not be able to manage this task in their teaching practice. The obvious solution for this problem would be to create new, high-quality textbooks. Such textbooks would provide teachers with tips for their own needs and values. Furthermore, we ought to teach students of Faculties of Education to recognize proper textbooks and show them how to work with them effectively.

\section{References}

Ball, D. L. \& Sharon, F. N. (1988). Using textbooks and teachers' guides: A dilemma for beginning teachers and teacher educators, Curriculum Inquiry, 18(4), 401-423. http://dx.doi.org/10.1080/ 03626784.1988.11076050.

Brown, A. (1992). Design experiments: Theoretical and methodological challenges in creating complex interventions in classroom settings. The Journal of the Learning Sciences, 2(2), 141-178. http://dx.doi.org/10.1207/s15327809jls0202_2.

DBRC Design-Based Research Collective. (2003). Design-based research: An emerging paradigm for educational inquiry. Educational Researcher, 32(1), 5-8. http://dx.doi.org/10.3102/ $0013189 \times 032001005$.

Dvořák, D. (2015). Dưraz školy na akademický úspěch: TIMSS 2011 jako sonda do reformy v České republice. Pedagogická orientace, 25(4), 583-604.

Dvořák, D., Dvořáková, M., \& Stará, J. (2008). Design based research - výzkum učebnic prováděný jejich tvůrci. In Učebnice z pohledu pedagogického výzkumu. Brno: Paido.

Grossman, P. \& Thompson, C. (2008). Learning from curriculum materials: Scaffolds for new teachers? Teaching and Teacher Education,24(8), 2014-2026. http://dx.doi.org/10.1016/j.tate.2008. 05.002.

Horsley, M., Knight, B. \& Huntly, H. (2010). The role of textbooks and other teaching and learning resources in higher education in Australia: change and continuity in supporting learning. IARTEM e-Journal, 3(2), 43-61.

Horsley, M. \& Sikorova, Z. (2014). Classroom Teaching and Learning Resources: International Comparisons from TIMSS - A Preliminary Review. Orbis Scholae, 8(2), 43-60. http://dx.doi.org/ 10.14712/23363177.2015.65. 
Janík, T. (2013). Od reformy kurikula k produktivní kultuře vyučování a učení. Pedagogická orientace, (23)5, 634-663. http://dx.doi.org/10.5817/PedOr2013-5-634.

Lambert, D. (1996). The choice of textbooks for use in secondary school geography departments: Some answers and some further questions for research. Paradigm, 21. [on-line] Retrieved from: http://faculty.education.illinois.edu/westbury/paradigm/Lambert.html.

Mikk, J. (2000). Textbook: Research and writing. Frankfurt am Main: Peter Lang.

Peacock, A. \& Gates, S. (2000). Newly qualified primary teachers' perceptions of the roles of text materials in teaching science. Research in Science \& Technological Education, (18)2, 155-171.

Pinar, W. F, Reynolds, W. M., Slattery, P., \& Taubman, P. M. (2004). Understanding the curriculum: An introduction to the study of historical and contemporary curriculum discourses, New York: Peter Lang.

Rambousek V., Fuglík V. \& Štípek J. (2015). Selected Outcomes of Research of Digital Competency Development on Elementary Schools. Journal on Efficiency and Responsibility in Education and Science, (8)2, 35-43, http://dx.doi.org/10.7160/eriesj.2015.080201.

Remillard, J. T. (2005). Examining key concepts in research on teachers' use of mathematics curricula. Review of Educational Research, (75)2, 211-246, http://journals.sagepub.com/doi/abs/ 10.3102/00346543075002211.

Rendl, M. \& Štech, S. (2012). Should learning (mathematics) at school aim at knowledge or at competences? Orbis Scholae, (6)2, 23-39.

Seoane, C. D. A. \& Rodríguez, J. R. (2014). Characteristics and Properties of the Didactic Materials Developed by Local Governments. IARTEM e-Journal, 3(2), 23-41.

Sikorová, Z. (2011). The role of textbooks in lower secondary schools in the Czech republic. IARTEM e-Journal, 4(2), 1-22.

Stará, J., Dvořáková, M., \& Dvořák, D. (2010). Design based research (DBR) a tři učitelé: setkání záměru inovace a reality implementace. In Váňová, R. \& Krykorková, H. et al., Učitel v současné škole. Praha: Univerzita Karlova.

Stará, J. \& Krčmářová, T. (2014). Užívání nových učebnicových materiálů učiteli 1. stupně ZŠ. Pedagogická orientace, 24(1), 77-11. http://dx.doi.org/10.5817/PedOr2014-1-77.

International Association for the Evaluation of Educational Achievement. TIMSS 2011 International Database. [on-line]. Retrieved from: https://timssandpirls.bc.edu/timss2011/internationaldatabase.html.

Wang, F., \& Hannafin, M. (2005). Design-based research and technology-enhanced learning environments. Educational Technology Research and Development, 53(4), 5-23. http://dx.doi.org/ 10.1007/BF02504682.

\section{Acknowledgement}

This work was supported by the Czech Science Foundation [grant number P402/12/G130].

\section{Contact:}

PhDr. Jana Stará, Ph.D.

Department of Primary Education

Faculty of Education, Charles University

M. Rettigové 4, 11639 Praha 1, Czech Republic

E-mail: jana.stara@pedf.cuni.cz

Tel.: +420221900182 
Jana Stará received her MA in primary school teaching and her Ph.D. in education from Charles University in Prague. She is currently head of the Department of Primary Education at Faculty of Education at Charles University. She teaches mainly didactics and leads the students' teaching practice. Her main research interests are implementing the prescribed curricula by teachers and teaching of social studies at primary school. She is also involved in developing the primary school textbooks for social studies and introducing education for global responsibility at primary school education and teacher training.

Karel Starý received his MA in teaching Czech language and history in secondary schools and his Ph.D. from Charles University in Prague. He works as a researcher in the Institute for Research and Development of Education at Faculty of Education at Charles University. He is interested in teachers' professional development, formative assessment and reading literacy. In these fields he does research, publishes and teaches.

Martin Chvál received his MA in theoretical physics and in education and his Ph.D. in education from Charles University in Prague. He is a researcher in the Institute for Research and Development of Education at Faculty of Education at Charles University. He teaches research methods for psychologists, evaluation in education and statistics in educational research in the doctoral program. He is an editor-in-chief of the peer-reviewed journal Pedagogika. His main research interests are evaluation and self-evaluation of schools and student assessment. 